\title{
En ung kvinne som mistet kraften i ett bein
}

\author{
Da en for øvrig sprek, ung kvinne gradvis mistet kraften i ett bein, var \\ det naturlig å mistenke at hun hadde arvet samme sykdom som hadde \\ ført til gangvansker i flere slektsledd. Molekylær diagnostikk viste at \\ dette var en annen sykdom enn antatt. En eksakt molekylær diagnose \\ gir både muligheter og utfordringer.
}

Se kommentar side 586 og kunnskapsprøve på www.tidsskriftet.no/quiz

\section{Trygve Holmøy \\ trygve.holmoy@medisin.uio.no \\ Nevrologisk avdeling}

Øivind Braaten

Avdeling for medisinsk genetikk

Inger Anette Hynås Hovden

Klinisk nevrofysiologisk laboratorium

Nevrologisk avdeling

\section{Chantal M. Tallaksen}

Nevrologisk avdeling

Oslo universitetssykehus, Ullevål

0407 Oslo

En tidligere frisk kvinne i slutten av 30-årene merket redusert kraft $i$ venstre ankel under trening. Hun hadde ikke vært utsatt for noe relevant traume. Tilstanden progredierte gradvis, og etter to år var leggen blitt synlig tynnere, og hun var moderat hemmet ved gange og betydelig hemmet ved løping og skigåing. Hun merket ingen symptomer fra høyre bein eller kroppen for øvrig. Kraftsvikten var ikke ledsaget av smerter eller andre sensoriske symptomer, og allmenntilstanden var god. Hennes far hadde utviklet gradvis redusert førlighet $i$ beina fra 60-årsalderen og hadde etter fem år betydelige gangvansker. Farmoren hadde også hatt økende gangvansker fra 40-50 års alder og brukt rullestol $i$ flere tiår før hun døde mer enn 90 år gammel.

Progredierende pareser og gangvansker hos både kvinner og menn $\mathrm{i}$ tre påfølgende slektsledd gjorde at man kunne mistenke nevrologisk sykdom med autosomalt dominant arvegang. En rekke sykdommer i nervesystem, skjelett og muskulatur kan imidlertid gi gangvansker. En mulighet var derfor at farmor, far og datter ikke hadde samme sykdom. Sykdommer med multifaktoriell årsak, for eksempel multippel sklerose, kan i sjeldne tilfeller også opptre i påfølgende slektsledd. Dette er imidlertid uvanlig når tre eller flere slektsledd er affisert.
Mens anamnesen er avgjørende for å kartlegge arvegangen, kan klinisk nevrologisk undersøkelse avdekke hvilke deler av nervesystemet som er affisert.

Ved undersøkelse hos nevrolog halvannet år etter sykdomsdebut ble det funnet tydelig muskelatrofi i venstre legg, som var $2 \mathrm{~cm}$ tynnere enn den høyre. Hun hadde parese for plantarfleksjon i venstre ankel og i tærne på venstre fot og klarte ikke å stå på tærne på denne siden. Det var normal kraft i høyre bein og i kroppen for øvrig. Sensibiliteten for stikk, berøring og vibrasjon samt leddsans var normal, også $i$ venstre bein. På venstre side var akillesrefleksen utslukket og plantarrefleksen indifferent. Ellers var senerefleksene normale. Det var ingen synlige fascikulasjoner. Nevrologen henviste pasienten videre til poliklinisk utredning med magnetisk resonanstomografi (MR) av hode, columna, bekken og lår.

Sykdom i det perifere nervesystem med affeksjon av nedre motornevron fører til slappe pareser med muskelatrofi og svekkede eller opphevede senereflekser (fig 1). Sykdom i sentralnervesystemet, slik som for eksempel multippel sklerose, cerebrovaskulær sykdom eller svulster, kan affisere øvre motornevron og gi sentralmotorisk parese med spastisitet, hyperrefleksi og inverterte plantarreflekser uten muskelatrofi. Vår pasient hadde kraftsvikt, muskelatrofi og svekkede senereflekser forenlig med perifer nevrogen affeksjon. Den indifferente plantarrefleksen på venstre side kunne kanskje representere et sentralmotorisk tegn. Det var imidlertid ingen andre sentralmotoriske tegn. Parese i stortåens fleksormuskler var derfor en mer sannsynlig forklaring på dette funnet.

Selv om sykehistorien tydet på en arvelig nevromuskulær sykdom, var det viktig å utelukke andre mulige årsaker. Inflammasjon eller kompresjon av S1-roten på grunn av skiveprolaps eller tumor i spinalkanalen, eller av perifere nerver i lysken (plexus lumbosacralis) eller i låret (nervus ischiadicus) kan gi progredierende pareser av den typen pasienten hadde, men vil vanligvis også gi sensoriske symptomer og funn. Inflammatoriske og nevrodegenerative sykdommer i sentralnervesystemet kan også gi progredierende pareser, og de sentralmotoriske tegnene kan være vanskelig å påvise dersom det også foreligger skade av det perifere nervesystemet.

$M R$ viste en $15 \times 4 \mathrm{~mm}$ stor intraspinal synovialcyste i relasjon til venstre intervertebralledd på nivå $L 3 / L 4$, uten tegn til kompresjon av nervevev. Det var ikke synlig patologi $i$ hjernen eller ryggmargen. Orienterende blodprøver var normale, med unntak av moderat økt kreatinkinase på 252 U/l (35-210), som var normalisert etter tre uker.

Moderat forhøyet kreatinkinase kan forekomme ved sykdommer med aktiv nedbrytning av skjelettmuskulatur, men også etter fysisk trening slik som hos vår pasient $\mathrm{i}$ forbindelse med den første målingen. Synovialcysten komprimerte ikke nervevev og var heller ikke lokalisert ved S1-roten som innerverer ankelens fleksormuskler. Den ble derfor tolket som et tilfeldig funn uten klinisk betydning.

Familieanamnesen og de kliniske funnene gjorde at arvelige polynevropatier var nærliggende differensialdiagnoser. CharcotMarie-Tooths sykdom har oftest autosomalt dominant arvegang og debuterer med perifere lammelser i beina, og er den desidert hyppigste formen for arvelig polynevropati. Paresene ved Charcot-Marie-Tooths sykdom er imidlertid typisk symmetriske og er ofte ledsaget av sensibilitetsendringer.

Flere andre sykdommer kan også føre til lammelser uten sensoriske symptomer eller funn, men har vanligvis annen klinisk presentasjon eller arvegang enn den som var mest sannsynlig i denne sykehistorien. Hereditær spastisk paraparese kan følge autosomalt dominant arvegang, men gir overveiende symmetrisk spastisitet i beina og varierende grad av pareser. Spinal muskelatrofi gir perifere lammelser i beina, men debuterer som oftest tidligere enn hos vår pasient og følger autosomalt recessiv arvegang. Myopatier rammer fortrinnsvis proksimal muskulatur, men sjeldne varianter som tibial muskeldystrofi følger autosomalt dominant arvegang og kan gi dominerende distale pareser (1). Multifokal motorisk nevropati med ledningsblokk kan gi asymmetriske pareser som hos vår pasient, men er ikke arvelig. 


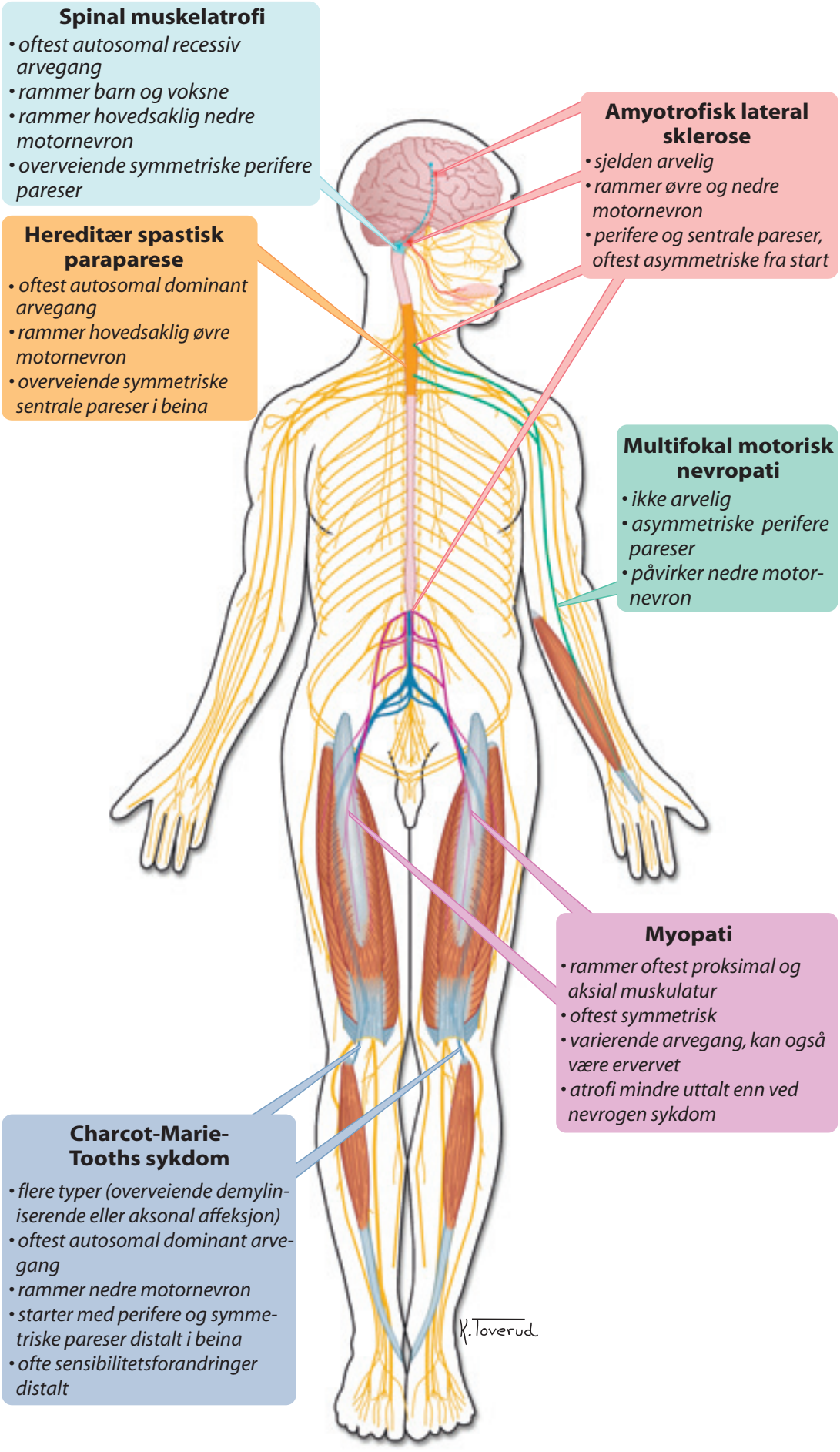

Figur 1 Skjematisk fremstilling av øvre og nedre motornevron. Primær anatomisk lokalisasjon for sykdommer som er omtalt i artikkelen er skissert

Ved nevromuskulære sykdommer kan nevrofysiologisk undersøkelse bidra til å kartlegge sykdomsprosessens lokalisasjon (perifer nerve, nevromuskulær synapse, muskel), utbredelse (subklinisk affeksjon i asymptomatisk muskulatur) og sykdomsprosess (skade av myelin, akson eller motornevroner).

Poliklinisk nevrografi drøyt halvannet år etter symptomdebut viste normal lednings- hastighet, men redusert amplitude $i$ venstre nervus tibialis. Det var normale funn i motoriske nerver i høyre bein og i sensoriske nerver bilateralt. Elektromyografi (EMG) viste rikelig spontanaktvitet, fibrillasjoner og positive skarpe bølger forenlig med pågående denervasjon $i$ venstre musculus gastrocnemius, mens det var normale funn i alle andre undersøkte muskler i begge bein. Fornyet undersøkelse etter åtte måneder viste mer uttalt denervasjonsaktivitet, men fortsatt bare i venstre $m$. gastrocnemius.

Den nevrofysiologiske undersøkelsen bekreftet den kliniske mistanken om en sykdom som selektivt rammet motoriske nevroner. Lave amplituder i perifere nerver tyder på skade av aksoner og ses blant annet ved en relativt sjelden form av Charcot-Marie-Tooths sykdom, CMT2. Den vanligste typen av CharcotMarie-Tooths sykdom (CMT1) fører til demyelinisering og nedsatt nerveledningshastighet, noe som ikke ble funnet hos vår pasient. Hereditære polynevropatier gir også typisk symmetrisk affeksjon i begge bein. Verken kliniske funn eller den nevrofysiologiske undersøkelsen ga holdepunkter for dette. Funnet av denervasjonsaktivitet ved elektromyografi tydet imidlertid på at sykdommen medførte tap av motornevroner. Dette var en viktig tilleggsopplysning, ettersom den kliniske undersøkelsen ikke hadde vist fascikulasjoner - et vanlig klinisk tegn på tap av motornevroner.

Det nevrofysiologiske funnet kunne passe med en lesjon i n. tibialis. Pasienten hadde imidlertid ikke korresponderende sensibilitetsendringer, og det var ikke radiologiske holdepunkter for nervekompresjon. Kombinasjonen av asymmetriske pareser og tegn til tap av motornevroner gjorde at motornevronsykdom måtte mistenkes, selv om sykdommen utviklet seg langsommere enn det som er vanlig ved amyotrofisk lateral sklerose (ALS). Det finnes imidlertid motornevronsykdommer som progredierer betydelig langsommere enn amyotrofisk lateral sklerose vanligvis giør. Ved såkalt isomelisk amyotrofi kan lammelsene holde seg relativt stasjonære i en ekstremitet gjennom flere år.

Asymmetriske og progredierende perifere pareser kan ses ved hereditær amyotrofisk lateral sklerose, som kan være forårsaket av mutasjoner i genet for superoksid dismutase (SOD1).

Snaut to år etter symptomdebut ble det utført sekvensering av SOD1-genet. Denne viste en adenin-til-guanin-punktmutasjon i nukleotidposisjon 140 (fig 2), som fører til at aminosyren histidin blir byttet ut med arginin i posisjon 46 i proteinet $(H 46 R$ eller p.His46Arg). Den samme mutasjonen ble senere også påvist hos faren. Det ble startet behandling med riluzol.

Sykdommen har fortsatt å progrediere langsomt. To og et halvt år etter symptomdebut har hun fortsatt kun symptomer fra venstre bein.

\section{Diskusjon}

Amyotrofisk lateral sklerose har en insidens på vel 2 per 100000 (2). Den rammer typisk både øvre og nedre motornevron og er den vanligste formen for motornevronsykdom. De fleste pasientene har ingen slektninger med sykdommen (sporadisk ALS), og årsaken er da ukjent. Om lag $10 \%$ har imidlertid nære slektninger som også har sykdommen 
(familiær ALS). Arvegangen er da som oftest autosomalt dominant, men ufullstendig penetrans kan medføre atypisk arvemønster (3).

Amyotrofisk lateral sklerose starter gjerne med asymmetriske pareser i arm eller bein, eventuelt i tunge og svelg, og fører vanligvis til respirasjonssvikt og død etter få år (4). Kombinasjon av perifere og sentrale pareser med fascikulasjoner og nevrofysiologiske tegn på denervasjon er typisk. Atrofi og kraftsvikt skyldes skade av nedre motornevron, mens hyperrefleksi, spastisitet og invertert plantarrefleks skyldes skade av øvre motornevron. Av og til fremkommer det typiske blandingsbildet først et stykke ut i sykdomsforløpet. Det kan også være vanskelig å påvise tegn til skade av øvre motornevron hos pasienter med svært uttalte perifere pareser. For eksempel vil man ikke finne invertert plantarrefleks dersom det er paralyse i stortåens ekstensormuskler. Diagnosen stilles ut fra typiske kliniske funn og ved påvisning av denervasjonsaktivitet ved elektromyografi i flere ekstremiteter. MR av hjerne, nakke og eventuelt rygg er viktig for å utelukke differensialdiagnoser, blant annet osteokondrose eller andre prosesser som komprimerer medulla og nerverøtter.

Ved arvelig amyotrofisk lateral sklerose kan både symptomer, kliniske funn og progresjonstakt noen ganger avvike betydelig fra det som vanligvis ses ved sporadisk amyotrofisk lateral sklerose $(5,6)$. Enkelte varianter kan ha et betydelig mer benignt forløp. H46R SOD1-mutasjonen som ble påvist hos vår pasient og hos hennes far, gir typisk relativt langsomt progredierende pareser i beina (7). Det er heller ikke uvanlig at sykdommen debuterer ved ulike aldre $\mathrm{i}$ samme slekt (3).

Koblingen mellom mutasjoner i SOD1genet og amyotrofisk lateral sklerose ble beskrevet i 1993, og er den hyppigste av de kjente årsakene til arvelig amyotrofisk lateral sklerose (8). Sannsynligvis fører mutasjonene til feilfolding og aggregering av toksisk SOD-protein (9). Selv om 152 ulike SOD1-mutasjoner er blitt beskrevet, forklarer disse mindre enn $25 \%$ av tilfellene med arvelig amyotrofisk lateral sklerose (10). Et negativt funn utelukker derfor ikke denne tilstanden. Sekvensering av SODl-genet kan være nyttig der flere slektninger har symptomer forenlig med motornevronsykdom, og undersøkelsen utføres ved Oslo universitetssykehus, Ullevål.

Når en mutasjon finnes hos flere affiserte slektninger som alle har et karakteristisk sykdomsbilde (7), er det sannsynlig at mutasjonen forårsaker sykdommen. SOD1-mutasjoner er imidlertid også blitt beskrevet hos opptil $7 \%$ av pasienter med sporadisk amyotrofisk lateral sklerose $(10,11)$. I slike tilfeller kan det være vanskelig å avgjøre hvorvidt mutasjonen faktisk forårsaker sykdommen. Dette er et viktig spørsmål, fordi det avgjør slektningers risiko for å utvikle lidelsen. SOD1-mutasjoner ved sporadisk

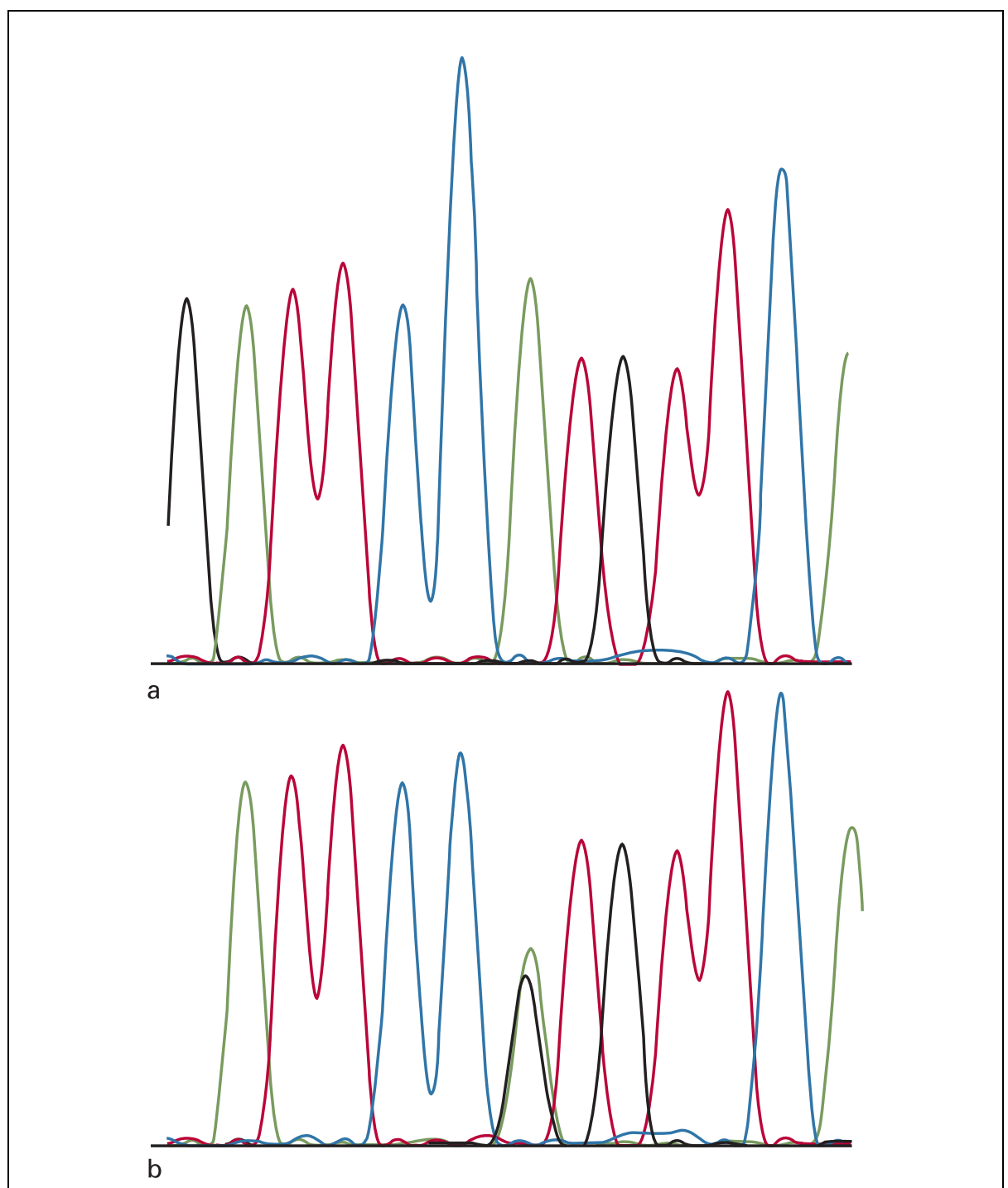

Figur 2 Sekvensering av det aktuelle området i SOD1-genet. a) En normal nukleotidsekvens med adenosin i homozygot form i den aktuelle posisjonen (høy grønn topp midt i bildet. b) Den muterte nukleotidsekvensen. Høyden på den grønne toppen er halvert og det er tilkommet en ekstra topp fordi en adenosin er substituert med guanin (c.140A > G)

amyotrofisk lateral sklerose kan forekomme hvis mutasjonen er nyoppstått, men også dersom en av foreldrene var bærer uten å få symptomer (redusert penetrans) eller dersom far ikke er biologisk far (non-paternitet). Det er også mulig at enkelte SOD1-mutasjoner fører til så små endringer i proteinet at de ikke forårsaker sykdom overhodet, for eksempel dersom en aminosyre substitueres med en annen som har svært lik størrelse og ladning. Man bør derfor være varsom med å analysere SOD1-genet hos pasienter som ikke har positiv slektsanamnese (12).

Amyotrofisk lateral sklerose er en alvorlig sykdom, og mye skremmende informasjon er lett tilgjengelig på Internett. Glutamathemmeren riluzol er den eneste behandlingen med dokumentert effekt, og den bremser sykdomsprogresjonen og forlenger livet med gjennomsnittlig $10 \%$, hvilket tilsvarer om lag tre måneder ved sporadisk amyotrofisk lateral sklerose (13). Effekten på pasienter med SOD1-mutasjoner er ikke undersøkt spesifikt, men ut fra kunnskap om sykdomsmekanismer og resultater fra studier av mus som er transgene for mutert SOD1, er det sannsynlig at de kan oppnå reduksjon i progresjonstakten. Det er derfor rimelig at de tilbys medikamentet, og at videre bruk avgjøres på grunnlag av subjektiv nytte og bivirkninger hos den enkelte pasient.

Som ved annen alvorlig arvelig sykdom kan påvisning av SOD1-mutasjon medføre en stor psykisk belastning for pasient og pårørende. På den annen side gir korrekt diagnose pasienten mulighet til å sette seg inn i egen sykdom og treffe rasjonelle valg samt gir mulighet for å delta i kliniske studier av nye medikamenter. Det er derfor viktig med informasjon og oppfølging fra nevrolog og genetiker som tilegner seg tilstrekkelig kunnskap om familiær amyotrofisk lateral sklerose. Disse må være forberedt på psykiske reaksjoner som kan følge diagnosen (14). 
En eksakt molekylær diagnose muliggjør prediktiv testing av asymptomatiske slektninger. Slik testing er underlagt spesielle bestemmelser i bioteknologiloven og er i utgangspunktet ikke tillatt hos barn under 18 år. Oppsøkende genetisk virksomhet er forbudt. Legen kan derfor ikke på eget initiativ informere pasientens slektninger om SOD1-mutasjonen. Ettersom behandlingsmulighetene er begrenset, vil det ofte være vanskelig for pasienten å avgjøre om, og eventuelt når, det er riktig å informere sine barn og andre slektninger om at de kan være bærere av mutasjonen. Slik informasjon vil sette slektningene overfor det vanskelige spørsmålet om de skal foreta prediktiv gentest. Denne kan med stor sikkerhet utelukke at man bærer sykdomsgenet, men utfallet kan like gjerne bli omvendt. Slektninger som blir klar over at tilstanden kan være arvelig eller får vite om testresultatet bør henvises til genetisk veiledning.

Ved arvelig amyotrofisk lateral sklerose og andre alvorlige arvelige sykdommer med begrenset behandlingsmulighet kan gravide kvinner/par søke om prenataldiagnostikk. Dersom mutasjonen hos den gravide eller hos faren er kjent, kan man utføre DNAanalyse av chorionvev. Før dette utføres må kvinnen/paret ha mottatt genetisk veiledning. Inngrepet utføres etter 11 fullgåtte svangerskapsuker og medfører en abortrisiko på snaut $1 \%$.

De omtalte personene har gitt samtykke til at artikkelen blir publisert.

Oppgitte interessekonflikter: Ingen

\section{Litteratur}

1. Bindoff $L$, Gilhus NE. The genetic basis of muscle disease. Tidsskr Nor Laegeforen 2003; 123 . 2588-92.

2. Seljeseth YM, Vollset SE, Tysnes OB. Increasing mortality from amyotrophic lateral sclerosis in Norway? Neurology 2000; 55: 1262-6.

3. Valdmanis PN, Daoud H, Dion PA et al. Recent advances in the genetics of amyotrophic lateral sclerosis. Curr Neurol Neurosci Rep 2009; 9: 198-205.

4. Mitchell JD, Borasio GD. Amyotrophic lateral sclerosis. Lancet 2007: 369: 2031 -41.

5. Eisen A, Mezei MM, Stewart HG et al. SOD1 gene mutations in ALS patients from British Columbia, Canada: clinical features, neurophysiology and ethical issues in management. Amyotroph Lateral Scler 2008; 9: 108-19.

6. Andersen PM, Sims KB, Xin WW et al. Sixteen novel mutations in the $\mathrm{Cu} / \mathrm{Zn}$ superoxide dismutase gene in amyotrophic lateral sclerosis: a decade of discoveries, defects and disputes. Amyotroph Lateral Scler Other Motor Neuron Disord 2003; 4: 62-73
7. Holmøy T, Bjørgo K, Roos PM. Slowly progressing amyotrophic lateral sclerosis caused by H46R SOD1 mutation. Eur Neurol 2007; 58: 57-8.

8. Dion PA, Daoud H, Rouleau GA. Genetics of motor neuron disorders: new insights into pathogenic mechanisms. Nat Rev Genet 2009; 10: 769-82.

9. Jonsson PA, Ernhill K, Andersen PM et al. Minute quantities of misfolded mutant superoxide dismutase- 1 cause amyotrophic lateral sclerosis. Brain 2004: 127: 73-88.

10. Andersen PM. Amyotrophic lateral sclerosis associated with mutations in the CuZn superoxide dismutase gene. Curr Neurol Neurosci Rep 2006; 6: $37-46$.

11. Jones CT, Swingler RJ, Simpson SA et al. Superoxide dismutase mutations in an unselected cohort of Scottish amyotrophic lateral sclerosis patients. J Med Genet 1995; 32: 290-2.

12. Andersen PM, Borasio GD, Dengler R et al. Good practice in the management of amyotrophic lateral sclerosis: clinical guidelines. An evidence-based review with good practice points. Amyotroph Lateral Scler 2007; 8: 195-213.

13. Bensimon G, Lacomblez L, Meininger V. A controlled trial of riluzole in amyotrophic lateral sclerosis. N Engl J Med 1994; 330: 585-91.

14. Fanos JH, Gelinas DF, Miller RG. «You have shown me my end»: attitudes toward presymptomatic testing for familial amyotrophic lateral sclerosis. Am J Med Genet A 2004; 129A: 248-53.

Mottatt 10.12. 2009, første revisjon innsendt 3.5 2010, godkjent 18.11. 2010. Medisinsk redaktør Mette Sagsveen.

\section{Kommentar}

\section{Når det vanligste ikke er forklaringen}

Genetisk diagnostikk får økende betydning i dagens medisin, ikke minst i nevrologi der arvelige sykdommer forekommer hyppig. Holmøy og medforfattere beskriver en pasient med en arvelig form for forhorncellesykdom som belyser dagens diagnostiske utfordringer og viser hvor viktig genetisk diagnostikk er for å stille en eksakt diagnose.

Kraftsvekkelse og muskelsvinn som rammer en legg vil ikke vanligvis reise spørsmål om arvelig amyotrofisk lateral sklerose. Nerverotsaffeksjon forårsaket av kompresjon eller affeksjon av nervus ischiadicus vil, som forfatterne skriver, være mer nærliggende å tenke på. Men aktuelle kasus gjelder en ellers frisk, ung pasient med to års progressivt forløp uten smerter eller sensibilitetsendring og en slektsanamnese som tyder på dominant arv. Selv om det kan være vanskelig å bekrefte at det er samme sykdom som ses hos slektninger, er slektsopplysninger viktige og peker i retning av arvelig sykdom. Nevrofysiologiske funn og eksklusjon av andre årsaker gjør at man i dette tilfellet må vurdere en arvelig forhorncellesykdom, inkludert den som er forårsaket av SOD1mutasjoner (1).

Affeksjon av forhorncellene (motornevronene) fører blant annet til kraftsvekkelse og muskelatrofi. De fleste voksne med motornevronsykdom har amyotrofisk lateral sklerose (ALS), som i Norge har en forekomst på ca. 2,5 per 100 000. Lidelsen debuterer vanligvis rundt 60 års alder og har en overlevelsestid fra diagnosetidspunktet på 3-5 år (2).

Arvelig amyotrofisk lateral sklerose utgjør cirka $10 \%$ av alle tilfellene og viser både dominant (vanligst), recessiv og kjønnsbundet arvegang (1). Den vanligste arvelige formen for amyotrofisk lateral sklerose forårsakes av mutasjon i superoksid dismutase (SOD1)-genet. Flere mutasjoner i dette genet er påvist med en viss korrelasjon mellom genotype og fenotype. Mutasjoner i SOD1genet finnes også blant pasienter med antatt sporadisk amyotrofisk lateral sklerose. I tillegg til arvelige former for amyotrofisk lateral sklerose, der forhorncellebetingede utfall er de klart dominerende kliniske funn, finnes det syndromer der amyotrofisk lateral sklerose-liknende utfall forekommer sammen med f.eks. frontotemporal demens, spastisk paraplegi og parkinsonisme (1).

Kasuistikken belyser hvor viktig det er å komme frem til en genetisk diagnose. Funn av en kjent sykdomsgivende mutasjon gjør videre utredning unødvendig. I tillegg gir funnet prognostiske opplysninger. Selv om genotype-fenotype-korrelasjon ikke alltid sammenfaller, kan sammenlikning av mange pasienter med samme mutasjon oftest si noe om utviklingen av sykdommen. For eksempel er den SOD1-mutasjonen som pasienten fikk påvist, assosiert med amyotrofisk lateral sklerose som starter asymmetrisk i ett bein, utvikler seg langsomt og sjelden gir bulbære utfall (3). Bulbære utfall er den vanligste årsaken til morbiditet og mortalitet hos pasienter med amyotrofisk lateral sklerose.

\section{Laurence A. Bindoff}

laurence.bindoff@helse-bergen.no

Institutt for klinisk medisin

Universitet i Bergen

og

Avdeling for nevrologi

Haukeland universitetssykehus

5021 Bergen

Oppgitte interessekonflikter: Ingen

\section{Litteratur}

1. Wijesekera LC, Leigh PN. Amyotrophic lateral sclerosis. Orphanet J Rare Dis 2009; 4: 3.

2. Seljeseth YM, Vollset SE, Tysnes OB. Increasing mortality from amyotrophic lateral sclerosis in Norway? Neurology 2000; 55: 1262-6.

3. Aoki M., et al., Mild ALS in Japan associated with novel SOD mutation. Nat Genet, 1993; 5: 323-4. 